\title{
«Å lære dem denne kunst»
}

«Så snur du bare barnet og lytter over lungene,» sa overlegen da vi var kommet halvveis i nyfødtundersøkelsen. Det hørtes enkelt ut, og stetoskopet kunne jeg jo bruke, men som fersk lege i spesialisering, barnløs og med svært begrenset erfaring $\mathrm{i}$ å håndtere mennesker på under fem kilo måtte jeg raskt innse at jeg ikke hadde den fjerneste anelse om hvordan jeg skulle flytte på den lille kroppen på en noenlunde profesjonell måte. «Å, ja - du må bare holde her, og så løfte litt, og så snu sånn.» $O g$ vips, så lå barnet sovende på magen og jeg hadde tatt mitt første steg på veien mot å bli spesialist i barnesykdommer.

Hvilke spesialiteter vi skal ha, hva spesialistutdanningen skal inneholde og hvor lang den skal være er blant temaene som har vært diskutert $\mathrm{i}$ arbeidet med spesialitetsstruktur, som har foregått parallelt i Legeforeningen og Helsedirektoratet de siste årene (1). Forslaget fra Helsedirektoratet, som nylig har vært ute på høring (2), inneholder flere store endringer i dagens spesialitetsstruktur, også det som gjelder selve utdanningen. Turnustjenesten skal inngå som del 1 av spesialiseringen, og utdanningsløpet skal bli mer strukturert og modulbasert. Muligheten for å få tellende tjeneste fra forskning og andre fag forsvinner. Direktoratet anslår at man samlet sett kan kutte inn den formelle spesialiseringstiden med omtrent halvannet år og ønsker å gjøre utdanningen mer strømlinjeformet og effektiv. Men skal vi sikre at vi utdanner gode spesialister, er vi i tillegg nødt til å se på arbeidshverdagen ute på sykehusene.

For det er her legen blir spesialist. Spesialistutdanning dreier seg om mer enn å tilegne seg teoretisk kunnskap. Kunnskapsgrunnlaget for diagnostikk og behandling endres hele tiden, og det som var beste praksis da spesialisten var ferdigutdannet for ti år siden, vil ofte være utdatert i dag. Men spesialisten er fortsatt spesialist - per i dag er det kun spesialistene i allmennmedisin som må fornye spesialiteten sin. Man er derfor ikke spesialist bare på grunnlag av at man har teoretisk oversikt over faget på et gitt tidspunkt. Det å bli spesialist er en modningsprosess. Gjennom sitt arbeid samler legen i spesialisering erfaringer som til sammen skal utgjøre en solid referanseramme for å kunne møte pasienter eller problemstillinger innenfor fagets avgrensning. Den stadig økende referanserammen vil gjøre legen i stand til å gjøre mer og mer selvstendige vurderinger som samsvarer med den faglige standarden innenfor spesialiteten. Legen i spesialisering skal lære seg håndverket som gjør det mulig å nyttiggjøre seg den teoretiske kunnskapen. Hun skal lære å betjene verktøyet, både det konkrete og det mer abstrakte, som er nødvendig for å stille riktig diagnose og tilby god behandling til hver enkelt pasient. Det kan være noe så basalt som teknikken for å snu et nyfødt barn - det er umulig å lære seg ved å lese en bok. Håndverk må læres gjennom praksis.

Den viktigste læringsarenaen for leger i spesialisering er den kliniske, eventuelt den praktiske, tjenesten. Det er der pasientene og problemstillingene befinner seg og det er der erfaringene skal høstes. Avgjørende for at erfaringene skal bli korrekt plassert i referanserammen, er mulighet for løpende supervisjon og tilbakemelding fra leger som kan mer, har møtt problemstillingen tidligere og kjenner faget fra innsiden. Strukturerte veiledningssamtaler, kurs og andre pedagogiske plattformer er viktige supplementer, men vil aldri kunne erstatte god, gammeldags mester-svenn-læring.

Spesialiseringen blir derfor aldri bedre enn det læringsforholdene på den enkelte avdeling legger til rette for. Arbeidsvilkår som sikrer god spesialisering, krever ressurser og bemanning nok til at erfarne og mer uerfarne leger kan jobbe sammen, med samme pasient og samme arbeidsoppgave. Kravet til «produksjon» må ikke gå på bekostning av tid til faglig utvikling. Vi hører ofte at legers arbeidsdag spises opp av administrative oppgaver. Kanskje bør vi også bekymre oss for at tiden til «legerettet» arbeid forsvinner. Morgenmøter, røntgenmøter, internundervisning eller bare en god faglig samtale i lunsjen er enkle poster å nedprioritere når produksjonen skal effektiviseres. De er desto viktigere arenaer for å sikre kunnskapsoverlevering. Det er på tide å slå et slag for de hverdagslige lege-lege-møtepunktene!

Små grep for å tilrettelegge for løpende supervisjon kan vi også gjøre selv ved å sikre fysisk nærhet i tid og rom mellom erfarne og uerfarne leger. Har overleger og leger i spesialisering kontorer og arbeidsstasjoner i nærheten av hverandre? Sørger tjenesteplanene for at de har poliklinikk samtidig på samme sted? Og har vi en kultur som åpner for å gi konstruktive tilbakemeldinger til hverandre uavhengig av hvem som er formell veileder for hvem? Arbeidsgivere som tydeligere vektlegger lære-bort-oppgaven til sine ansatte, vil også ha gevinst ved at mer erfarne leger får et ekstra incentiv til å holde kunnskapene sine og håndverket sitt ved like.

Avleggelse av den hippokratiske ed er fortsatt et ritual i enkelte land. Et helt avsnitt $\mathrm{i}$ eden er viet plikten til å lære bort faget sitt «å lære dem denne kunst», som det heter i den norske oversettelsen (3). En tilsvarende formulering er tatt inn i Etiske regler for leger: «En lege bør etter sin kompetanse bidra til utvikling og formidling av den medisinske viten» (4). Det krever at vi har rom i arbeidshverdagen til å overlevere kunnskapen, til å få og gi tilbakemeldinger, diskutere fag og faglige avgjørelser der de dukker opp underveis. Slik utdanner - og opprettholder - vi gode spesialister.

\footnotetext{
Litteratur

. Torgersen J. Ny spesialitetsstruktur. Tidsskr Nor Legeforen 2014; 134: 2008

2. Helsedirektoratet. Legers spesialitetsstruktur og organisering av akuttmottak. Høring 18.6.2014. www.helsedirektoratet.no/Om/hoyringar/Sider/ legers-spesialitetsstruktur-og-organisering-av-akuttmottak.aspx (20.10.2014) 3. Skatvik F. Den hippokratiske ed. Store norske leksikon. https://snl.no/Den_hippokratiske_ed (20.10.2014).

4. Legeforeningen. Etiske regler for leger. Paragraf 10. http://legeforeningen.no/ Om-Legeforeningen/Organisasjonen/Rad-og-utvalg/Organisasjonspolitiskeutvalg/etikk/etiske-regler-for-leger/ (20.10.2014).
} 